\title{
STUDENTS’ PERSPECTIVE OF ENGLISH ONLINE LEARNING DURING COVID-19 PANDEMIC
}

\author{
Ianatuz Zahro \\ IKIP PGRI Jember \\ zahroana419@gmail.com
}

\begin{abstract}
This study aimed to know the students' perspective of English online learning during Covid-19 pandemic regarding readiness aspect, learning performance, and the obstacles students face in learning distance. This study used qualitative research and it was conducted from September until January in 12 meetings of distance learning using online applications. The questionnaires were given to 42 first-semester students of social faculty of IKIP PGRI Jember. The result showed that almost all students had good preparation before joining English online learning. However, students faced some main problem during online learning: unstable internet connection, losing their concentration starring at the screen of hand-phone or computer, and spending more money to buy internet quota. In conclusion, there were students' perspective in English online learning, i.e. 1) students have good English motivation motivation; they prepare the equipment needed before joining the online learning. 2) The lecture's style to teach English, students prefer to use the bilingual method to make them easier to understand the materials. 3) Google meet and zoom applications are the most chosen application used in virtual meetings because they provide good interaction between teachers and students. 4) The obstacles in online learning faced by students. i.e. unstable internet, lose concentration.
\end{abstract}

Keywords: Students' perspective, English online learning, covid 19 pandemic

\section{A. INTRODUCTION}

oronavirus Disease (Covid) 19 progression is still very worrying at this time. The
case of the victim increases rapidly; both in terms of deaths and victims who are
positive for Covid-19. This virus has become a global pandemic and it has a big effect in various sectors, the effect of the Coronavirus disease 2019 (Covid-19) pandemic also spread to the education sector (Abidah, et all. 2020). Coronavirus or Coronavirus Disease 20190 (Covid-19) is an infectious disease that attacks the human respiratory system caused by a new type of virus, namely SARS-CoV-2 (Severe Acute Respiratory Syndrome Coronavirus 02) (Sugihantono et al, 2020). And the World Health Organization (WHO) determined Covid19 as a global pandemic on March 11, 2020. Furthermore, in Indonesia, the pandemic had spread to all 34 provinces by April 2020. Jakarta, West Java, and Central Java are the worst-hit provinces, together accounting for more than half of the national total cases (Wikipedia).

Moreover, the Ministry of Education and Culture has released issued a policy of distance learning during covid-19. The policy concerns the implementation of education from home. Based on the policy, there are some regulations in applying learning from home; the teacher should give a meaningful learning experience for students, the teacher should understand the students' characteristic and condition to provide learning activities based on their interest, the 
teacher provides useful feedback qualitatively for the results of learning activities carried out by students.

This pandemic had led education to have a new method of teaching instead of face-toface learning become distance learning (Almanar, 2020) and changing conventional teaching and learning method to online learning and it makes a challenge for teachers and students to conduct their online class (Ariyanti, 2020) and this changing method is certainly not an easy and simple job (Atsani, 2020). The shifting from conventional classrooms to online classes requires the teacher to find the right solution to achieve the goal of learning; what kind of method and what application that suitable for the students can be applied in online learning. In fact, in face-to-face learning the teacher could motivate, controlling, giving clear explanations without any trouble directly. And teacher could see the students' responses directly. In practice, when we learn English face-to-face, many activities and abilities must be mastered; listening, speaking, writing, and reading. However, all those daily learning should be changed and bring to the online class. In distancing learning, the responsibilities of the students and their awareness in joining online classes are the main points to meet the goal of English learning. Awareness of learners to self-learning will help them to learn easily in the online classroom (Rifiyanti, 2020).

Since the covid-19 pandemic occurred, all lecturing at IKIP PGRI was delivered through online class as well English subject and it is carried out more than one year. There were some efforts have been done by the lecture at the beginning of the semester, i.e make sure that all students already installed some applications needed to support online class and giving short course how to use a certain application. Therefore, the writer conducted a study in her online class to know students' perspective of English online learning during covid-19 pandemic

\section{B. REVIEW OF LITERATURE}

In the current situation while covid-19 pandemic is happening, distancing learning becomes the best solution in the education sector to stop virus spread. Purely online courses are courses delivered entirely over the internet, and hybrid or blended learning combines traditional face-to-face classes, learning over the internet, and learning supported by other technologies (Bliuc, Goodyear, \& Ellis, 2007; Hoic-Bozic, Mornar, \& Boticki, 2009; Osguthorpe \& Graham, 2003, in Nguyen 2015). The stable internet is a major factor in the implementation of online classes, it will be able to provide a world-class education to anyone, anywhere, and anytime (Nguyen, 2015). 
Furthermore, the interaction between students and teachers is implemented in the online context. The principle of teacher-to-student interactions are; providing online interaction and synchronous session, giving feedback in assessment and discussion session both formal and informal, giving an appropriate response to question and queries, setting learning objectives, giving guidance, and being organized (Dyment, J. et all., 2020), (Martin, F. and Bolliger, D. U. 2018), Tanis, C. J. (2020), (Watson, F. F.,et all., 2017).

In the process of online learning engage more processes than in conventional learning (Chang SL, 2004) and teacher should bring the material into online and set up all learning activities in it, however, it is not enough to simply move teaching material directly to online material, but how lecturers can connect with their students is one of the most important aspects in online learning through appropriate learning instructions. Besides, to meet the various students' differences, students time table, external commitment, and assessment, online learning needs careful planning and maximizing of available technologies (Roddy, et. al., 2017). Furthermore, according to Chang SL (2004), there are four principles of instructional that lead the teacher to set up how the online learning must carry out to meet the goal of learning: 1) in accessing online materials, guide the students for preparing and maintaining an effective. workstation. 2) Employ advanced web navigation organizers. 3) Arrange instructional materials for easy online handling. 4). Organize instruction to encourage students' creation of personal cognitive strategies for effective comprehension. Besides, Alberth (2011) design six critical success factors for online language learning: characteristics of teacher and students, pedagogy, provision of support for both instructors and students, technology and language skills characteristics.

Besides, the important one in online learning both teachers and students must know about technology. It has an important role in the processes of English language learning and teaching (Williams, 2016) has a prominent position to create a new technique that can be more effective than before (Manan, 2017). They will use some technology and online platform to support the online class process. Technological developments in the industrial 4.0 era, make it easier for a teacher to teach (Rifiyanti, 2020). The teacher has to choose the right online applications for the English classroom. Online teachers need to know about technology or the ability of technical background to use new technology which can be delivered in teaching online both effectively and efficiently. Efficiency is a teacher's ability or competence to deliver the maximum amount of knowledge in the shortest possible time and at the lowest possible price or energy (Cooperman 2017). 
Furthermore, technology plays a dominant role in the teaching and learning process (Manan N A, 2017), especially in this pandemic situation. By using technology online learning can be done. Online learning needs the assistance of mobile applications that can be used to access information anywhere and at any time, such as smartphones, tablets, and laptops. (Gikas \& Grant, 2013). Some applications can be used in online learning such as Google Meet and Zoom for virtual meeting, e-learning, and WhatApp could be used in discussing. In processing online classes, it needs internet networks with accessibility, connectivity, flexibility, and the ability to generate various types of learning interactions (Moore, Dickson-Deane, \& Galyen, 2011).

In line with the current situation, previous research had been conducted by Vanderbilt University related to online learning. It explains why online learning is so often debated because there are many supposed advantages and uses of online learning. Some of the most important ones are: its effectiveness in educating students, its use as professional development, and the possibility of providing a world-class education to anyone with a broadband connection (Nguyen, 2015).

\section{METHOD}

\section{Respondents}

The respondents of this study were first-semester students of the Institute of Teachers Training (IKIP), Republic of Indonesia Teachers Association (PGRI) Jember (IKIP PGRI Jember). They were taken from social education faculty which consists of 42 students from three different programs; 12 students were from economic education program, 12 students were from Pancasila and Civic Education program, and 12 students were from History education program. This research was conducted in the odd semester from September until January in 12 meetings of distance learning using online applications, the students were asked to give their responses towards their English learning evaluation.

\section{Instrument}

This research used survey and interview methods. The survey method is a technique of collecting data from samples in a population using a questionnaire instrument (Adiyanta, 2019). According to Miles, Huberman \& Saldana (2014) research questionnaire represent the facets of inquiry that the researcher most wants to explore (Miles, 2014). On research with the survey method, data collection using a questionnaire and interviews from a sample form people (Islamy, 2019). The questionnaire was developed to explore students' perspective of English online learning during Covid-19 pandemic; readiness aspect, learning performance, 
lecture's style, the obstacles faced by students in online learning. There were two kinds of questionnaires used in this research; multiple-choice questions and open-ended questions. Regarding readiness, learning performance, and lecture style in teaching were set in multiplechoice questions form, meanwhile, the obstacles faced by students of online learning presented in open-ended questions.

\section{Procedure}

The first step of this study was to determine the respondents. 42 students of the Institute of Teachers Training IKIP PGRI Jember were taken from the first semester of social faculty. In the next step, the researchers did the observation for 12 meetings and then set some questions through Google form related to English teaching through online learning.

\section{Data Analysis}

This research used qualitative research. Qualitative research is conducted through intense with participants in a naturalistic setting to investigate the everyday and/or exceptional lives of individuals, groups, societies, and organizations (Miles, Huberman \& Saldana, 2014).

Qualitative research is one way in which research closely with data which is in the form of narratives and the sources are obtained from interviews, observation, and documentation (Wahidmurni, 2017). The data sources obtained were primary and secondary data. Primary data comes from surveys and interviews, while secondary data comes from various relevant literatures as support. The data obtained is then processed and analyzed in descriptive qualitative.

\section{FINDING RESULT AND DISCUSSION}

\section{Students' Readiness}

Regarding with readiness aspect, the students have good readiness before joining online class: the data showed that $88,1 \%$ always prepare the necessary tools before starting online class, such as English handbook, smartphone or computer device and 11,9\% of students sometimes prepare the equipment. Besides that, $83,3 \%$ of students always look for a good place where a good internet network available and even they went to free WiFi spot, 9,5\% sometimes, and 7,1\% never look for a good place with a good internet network (Figure 1). 

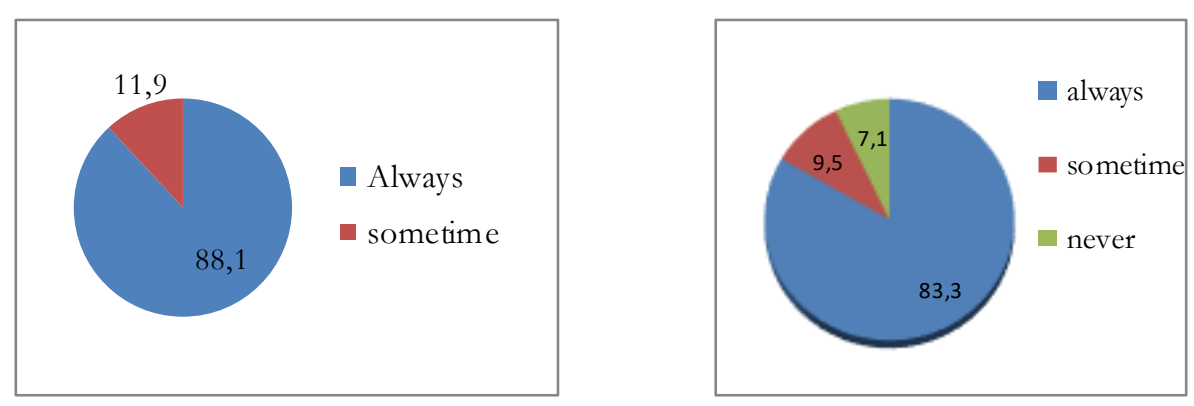

Figure 1 Students' Readiness in joining online learning

\section{Learning Performance}

The lecture's style in teaching English online learning, the data showed that $92,9 \%$ of students prefer the bilingual method and only 7,1 who were neutral. Furthermore, 90,5\% of students feel excited and give more attention in English online class when the lecture presents the materials. Besides, during online learning, $76,2 \%$ of students felt comfortable and face a challenge to ask in discussion sessions related to the material given, $17,7 \%$ of students felt neutral and 7,1\% felt uncomfortable in online learning. Besides, $66,7 \%$ of students' got good feedback from the teacher in a discussion session, 19\% were neutral and 14,3\% of students stated did not get any feedback (figure 2).
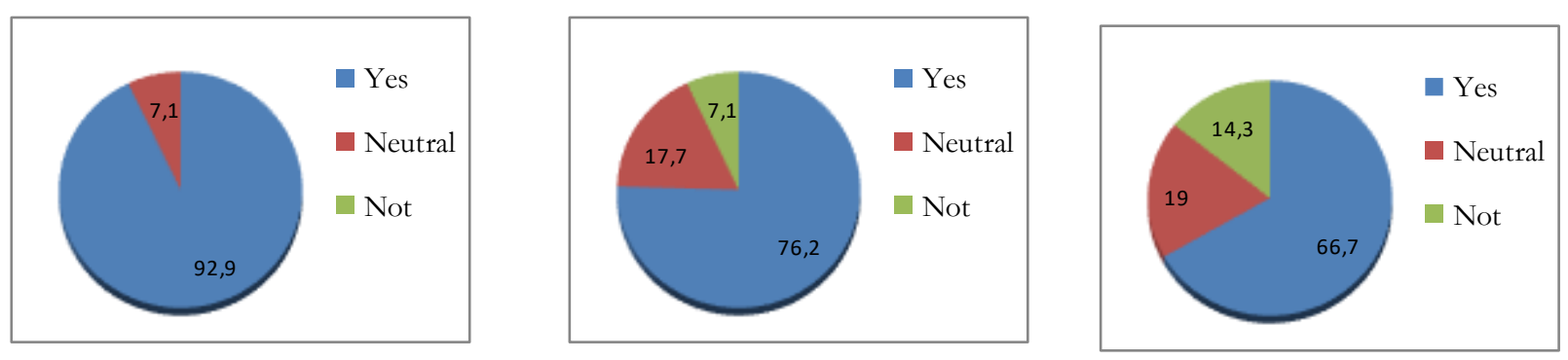

Figure 2: Lecture's style in Teaching English online learning

On the other hand, the data showed $45,2 \%$ of students assumed that their educational/scientific needs, especially in English courses, were not fulfilled by online learning compared with face-to-face learning, 23,8\% were doubt and $31 \%$ of students said not. Furthermore, half of the students felt bored and often lose their concentration in online learning (Figure 3). 


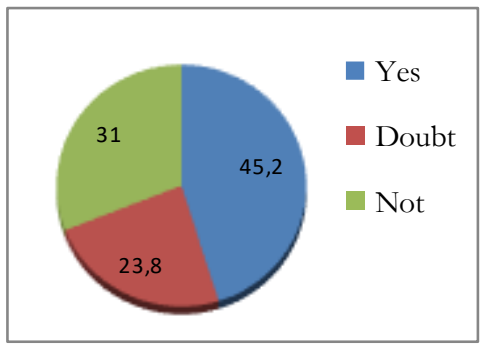

Figure 3: Students' experience in Teaching English online learning

Furthermore, an online application used by the lecture in online language learning, almost $50 \%$ of respondents choose Google meet or zoom in presenting material, they felt in the virtual meeting could understand more about the material and they could see their lecture and friends. $30 \%$ of students choose WA application, and $20 \%$ of students prefer e-learning (figure 4).

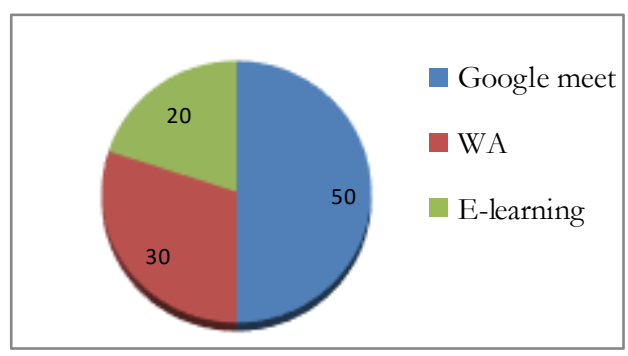

Figure 4: Application used in teaching online learning

\section{The obstacles of learning distance}

Related to this topic, the researcher presents open-ended questions. Here the table of student's evaluations related to some obstacles in online learning.

Table 1. Students' responses related to the obstacle in online learning.

\begin{tabular}{|l|l|}
\hline 1 & Unstable connection and lose connection in the middle of online learning are the main problem \\
\hline 2 & Using Google-meet in virtual meeting drained my quota so much \\
\hline 3 & I felt the material explanation was often not clear due to unstable connection \\
\hline 4 & I could not hear my teacher voice well due to the bad connection \\
\hline
\end{tabular}

The main problem of distance learning is the internet network. Some problems related to connection occur in teaching online, such as in the middle of lecturing students lose their connection and must rejoin in the online class. Besides that, the material given by the teacher did not receive maximally by students and it makes students face difficulties in understanding the new material.

\section{E. CONCLUTION}

Based on the discussion, students have good preparation before joining the online classroom. Furthermore, in delivering English material, teacher should use bilingual language 
to make them easier to understand the materials. Meanwhile, there are two platforms used in virtual meeting which provide good interaction between teacher and students, namely Google meet and Zoom. However, the success of the implementation of online learning depends on the internet network. Internet connection is the major factor, several problems arise due to unstable internet; the material didn't deliver well, students could not hear the teacher's voice. Thus, the findings of the students' perspective of English online learning become an input to the teacher particularly to make the better teaching and to improve the teaching quality to meet the goal of learning.

\section{REFERENCES}

Abidah, A., H N Hidaayatullaah, R M Simamora, D Fehabutar, L Mutakinati. (2020). The Impact of Covid-19 to Indonesian Education and Its Relation to the Philosophy of "Merdeka Belajar. Studies in Philosophy of Science and Education (SiPoSE) Vol.1, No.1, April 2020, pp. 38-49

Adiyanta, F.C.S. (2019). Hukum dan Studi Penelitian Empiris: Penggunaan Metode Survey sebagai Instrumen Penelitian Hukum Empiris. Jurnal Adminitrative Law \& Governance Journal, Vol. 2, No. 4, November 2019

Alberth. (2011). Critical Success Factors In Online Language Learning. TEFLIN Journal, Volume 22, Number 1, $\quad$ February 2011. https://journal.teflin.org/index.php/journal/article/view/16/19

Amir, L.R., Tanti, I., Maharani, D.A. et al., (2020). Student Perspective of Classroom and Distance Learning During COVID-19 Pandemic in the Undergraduate Dental Study Program Universitas Indonesia. BMC Med Educ 20,392 (2020). https://doi.org/10.1186/s12909-020-02312-0

Ariyanti, (2020). EFL Students' Challenges towards Home Learning Policy During Covid-19 Outbreak. Indonesian Journal of English Language Teaching and Applied Linguistics Vol. 5(1), 2020 www.ijeltal.org

Atsani, K. L. G. M. Z. (2020). Transformasi media pembelajaran pada masa Pandemi COVID-19. Al-Hikmah, 1(1), 82-93.

Bartley, S. J., \& Golek, J. H. (2004). Evaluating the Cost Effectiveness of Online and Face-toFace Instruction. Educational Technology \& Society, 7(4), 167-175

Chang, SL, 2004. Instructional Principles for Online Learning. University of Houston Clear Lake. from https:// files.eric.ed.gov/fulltext/ED485132.pdf.

Cooperman, L. (2017). The Art of Teaching Online: How to Start and How to Succeed as an Online Instructor. Chandos Publishing 
Digital Learning and Assessment. Principle of online learning. King's Collage London. from https://www.kcl.ac.uk/teachlearntech/principles-of-online-learning

Giatman, M., Haq, S., \& Pratama, Y. F. (2019). Effectivity of Online Learning Teaching Materials Model on Innovation Course of Vocational and Technology Education. Journal of Physics: Conference Series, 1387(1), 012131.

Gikas, J., \& Grant, M. M. (2013). Mobile computing devices in higher education: Student perspectives on learning with cellphones, smartphones \& social media. Internet and Higher Education. https://doi.org/10.1016/i.iheduc.2013.06.002

Islamy, Izzul. 2019. Penelitian Survei dalam Pembelajaran dan Pengajaran Bahasa Inggris. Purwokerto: Universitas Muhammadiyah Purwokerto

Julius Rozenfeld, Efficiency in Teaching English as a Foreign Language. De Gruyter DOI: 10.1515/rjes-2017-0016

Miles, M.B., \&Huberman, A.M \& Saldana, J. (2014) Qualitative Data Analysis. California: SAGE Publication. Inc

Moore, J. L., Dickson-Deane, C., \& Galyen, K. (2011). E-Learning, online learning, and distance learning environments: Are they the same? Internet and Higher Education. https://doi.org/10.1016/j.iheduc.2010.10.001

Nguyen, Tuyan. (2015). The Effectiveness of Online Learning: Beyond No Significant Difference and Future Horizons. MERLOT Journal of Online Learning and Teaching, Vol. 11, No. 2, June 2015, pp.309-319

Rifiyanti, Hafizah. 2020. Learners' Perceptions of Online English Learning during COVID-19 Pandemic. SCOPE: Journal of English language Teaching, Vol. 05, Issue 01, September, 2020, pp. 31-35 http://dx.doi.org/10.30998/scope.v5i1.6719

Roddy, C., et. al. (2017). Applying best practice online learning, teaching, and support to intensive online environments: an integrative review. Frontiers in Education, November, 2020, pp. 1-10. https://doi.org/10.3389/feduc.2017.00059

Sugihantono, Anung, 2020. dkk. Pedoman Pencegahan dan Pengendalian Coronavirus Disease 2019 (Covid-19). Jakarta: Kemenkes RI

Wahidmurni. 2017. Pemaparan Metode Penelitian Kualitatif. Malang: UIN Malang

Williams, C. Research Methods. Journal of Business \& Economic Research, Vol 5, No 3, March 2007, pp.65-72

Williams, D. (2016, September 14). How an LMS Supports English Language Teaching. Topyx: The Learning Platform. https://www.topyx.com/lms-blog/lms-supportsenglish-language-teaching-workplace 